\title{
The role of human activities in streambank
}

\section{stability: Lower Sakarya River (NW Turkey)}

\author{
Umit Duru \\ Department of Geography \\ Sakarya University \\ Sakarya, Turkey \\ umitduru@sakarya.edu.tr
}

\begin{abstract}
The main objective of this study is to determine historic and current human impacts on streambank stability in Lower Sakarya River. Remote sensing and Geographical Information System techniques with conjunction fieldworks were performed in order to identify the impact of human alteration on streambank stability in the riverine environment, $8.1 \mathrm{~km}$ along Sakarya River, the western portion of Sakarya province. Historical streambank movements were analyzed from Landsat satellite images in 1995, 2002 and 2016, respectively. As results, a significant land use changes have been observed along the river's floodplain. Recently, change in land use type from agricultural to urban usage has been observed in the region. The stream channel also became more stable and straight because man-made modifications including a hydropower dam constructed in $\mathbf{2 0 1 0}$ primarily reduced flood frequency, water velocity, stream power, shear stress on sediment particles deposited along the streambank. On the other hand, instream mining activities in the region disturb active streambanks, which raise a concern about instability of streambank and potential damage to infrastructures. Such studies are extremely important for understanding basic mechanisms of streambank evolution for further river restoration practices.
\end{abstract}

Keywords - streambank stability; anthropogenic effects; GIS; Sakarya River

\section{INTRODUCTION}

Streambank stability is here defined as the resistance of channel bed to natural and anthropogenic changes, and its resilience through years. Besides natural processes, the rate of streambank stability can be greatly altered by human modifications (channel modifications, reservoir constructions, land use/cover changes etc). Although such activities are crucial for development, they may have adverse effects in riverine environment. Human modified the environment to suite their demand and how people adapt to prevail environment is explained by Human environment interactions by the National Council for Geographic Education and the Association of American Geographers. Instream modifications usually lead to a noticeable decrease in bank erosion; channel migration so far as native species conserved in a riparian zone. Human induced changes in a stream channel may culminate in numerous environmental and socioeconomic consequences including loss of riparian zones and damage in infrastructures. For example, concrete armoring channels demolish the species in riparian areas, and removing riparian vegetation can also alter the morphology and natural dynamics of rivers $[1,2]$.

The rivers response anthropogenic activities with several channel parameters for instance incisions, narrowing, migration etc. [3]. These parameters are mainly resulted from disturbing the equilibrium of river dynamics and accelerate the rate of bank erosion. Human induced river bank erosion may become a natural disaster when people destroy natural species and settled within riparian zone, at least $100 \mathrm{~m}$ wide each side. [4] reported that narrower buffers provide habitat benefits for many species; however, protecting various riparian communities requires at least $100 \mathrm{~m}$ buffer zone. Numerous researches have made significant contribution on alteration of human activities in stream channels such as instream mining operations [5], dam or bridge contractions [6, 7]; channel restorations [8]; and land use/cover changes [9]. Yamani et al., [9] reported that anthropogenic activities have more superior impacts on river dynamics than natural events.

Human activities can cause drastic changes to the fluvial geomorphic stability of stream channel as a geological agent, respect to leaving some fingerprints on the earth surfaces. In order to examine how human alterations historically impact stream channel, Remote Sensing (RS) and Geographical Information System (GIS) techniques have become widely used in the last decades because remotely sensed images provide historical snapshot of stream channel displacements utilizing digital imageries. A reliable monitoring of temporal water resource dynamics using an integrated approach of RS and GIS enable to track historical changes among time intervals [10]. The main objective of the study is to assess how streambanks response land use changes in the floodplain of Sakarya River through years, and discuss potential factors controlling streambank stability in the last decades. Such studies are becoming extremely important for better understanding of current settings, the future and past stream channel evolution, which can be used further stream restoration practices. 


\section{STUDY AREA}

The Sakarya River is located in the northwest Anatolian region of Turkey, a length of approximately 820 km (Figure 1). The basin area of Sakarya River is nearly $54.000 \mathrm{~km}^{2}$, which is the third largest basin in Turkey. The study area, a length of $8.1 \mathrm{~km}$ and $200 \mathrm{~m}$ wide each side, is situated between D-100 highway to Historical Sakarya Bridge, west of the Sakarya province. The mean annual precipitation in the region is $775 \mathrm{~mm}$, the most of the precipitation falls during winter (32.6\%); precipitation rate seen in the summer $(19.7 \%)$. The region experiences semihumid characteristics.
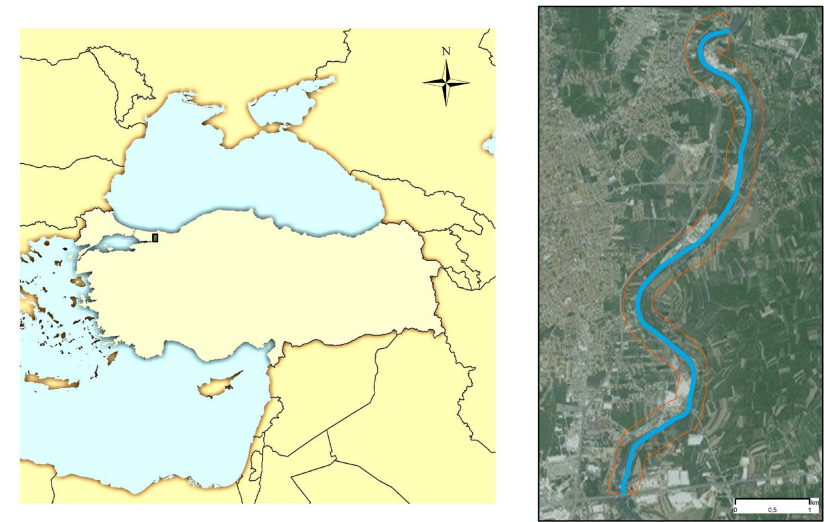

Fig. 1. The location map of study area.

The study area lies on alluvial deposits formed late Pliocene - Quaternary with gentle slopes. The mean annual discharge of $250 \mathrm{~m}^{3} / \mathrm{s}$ is observed at Botbasi gaging station (1243), which the closest gages recording stream flow. In the region, 3 ongoing instream mining operations, 2 out of order mining operations, 1 dam construction and 2 bridges leave significant fingerprints riverine environment. Moreover, an ongoing project respecting river restoration (e.g. concrete armoring of streambank, diversions of river) was recently started in the region. The western portions of the Sakarya River have a higher population density and are mainly characterized by alluvial plains. In the regions with higher population density, people settled in riparian zone.

\section{MATERIALS AND METHODS}

Various datasets were used to observe streambank stability in the region. The main input dataset utilized to monitor historical streambank changes are Landsat 1-5 Multispectral Scanner (MSS), Landsat-7 Enhanced Thematic Mapper Plus (ETM+) and Aster GDEM images obtained from United States Geological Surveys (USGS), Earth Explorer website (http://www.earthexplorer.usgs.gov) for a period from 1995 to 2016. All these images in Table 1 provide historical land use changes along urbanized portion of Sakarya River. Water discharge data from 1960 - 2002 at Botbasi gaging station (1243) was collected from State Hydraulic Works of Turkey (DSI). In addition two field works in 7 January 2017 and 14 March 2017 were conducted to collect data and relevant photographs of the Sakarya River sites where the anthropogenic activities are more pronounced.

Aster GDEM in $30 \mathrm{~m}$ resolution was used to delineate the $200 \mathrm{~m}$ buffer zone along the river. Then the Landsat images were utilized to extract land use maps. The discrete streambank lines were delineated from the multi-temporal images in ERDAS 9.2 software, and then all input data were transported as new shape files into ArcGIS 10.1 software. The comparison of the land use changes were analyzed from three different images in the three phases 1995 - 2002 (7 years), 2002 - 2016 (14 years), and 1995 2016 (21 years)

TABLE I. RESOLUTION OF SATELLITE IMAGES UTILIZED IN THE RESEARCH

\begin{tabular}{ccc}
\hline $\begin{array}{c}\text { Acquisition } \\
\text { date }\end{array}$ & Satellite/sensor & $\begin{array}{c}\text { Resolution } \\
\text { Spactral } \\
(\mathrm{m})\end{array}$ \\
\hline 9/July/1995 & Landsat MSS & 30 \\
10/May/2002 & Landsat MSS & 30 \\
15/July/2016 & Landsat ETM+ & 30 \\
04/June/2011 & Aster GDEM & 30 \\
\hline
\end{tabular}

Supervised classification method was considered an appropriate method for streambank detection, so measure the changes in land use and its effects on streambank stability were assessed in the last 21 years. Field work was carried out to observe human impact on Sakarya River. Along the riparian zone of the studied stream, dam construction, instream mining activities, bank rehabilitation works observed during the field work. The flow characteristics are also analyzed by some basic statistical techniques in MS Excel.

\section{RESULTS AND DisCUSSIONS}

The Sakarya River changed its bank based upon bank erosion, deposition caused by changes in flow characteristics, flood event, and land use change in the last two decades. Based on the field work observations, the eastern course of the bank has been eroded more especially at the sites surrounded by finer grain size. Cohesionless sand formation is the most dominant in the streambanks, so streambank erosion occurs with lower stream discharge due to lower bed shear stress for sediment transport. During the field work, boarder of perennial shrubs and trees were examined to define active channel boundary and historical channel migrations because vegetation cannot be excluded in the context of displacement in a streambank.

Adasu hydroelectric power station (HES) was constructed in the upstream of the reach in the year of 2010. The power station not only caused a reduction of channel flow, but more importantly flow regimes. The power dam also reduces stream velocity caused decreased in stream power, and the river is transport limited after its operation. After the Adasu HES operation more steady stream characters were observed due to primarily reduced flood frequency, water velocity, stream power, shear stress on sediment particles deposition along the streambank. Fluvial processes cannot be developed at low discharge of water. Despite variation in channel characteristics may occur, the implementation of a dam does not always causes geomorphic changes [3].

İnstream sand extraction operations on point bars along the stream channel have also loosened the stream bank correspondingly altering channel morphology. Sand extractions in the region have a direct impact on changing 
streambank properties such as removing sands from point bars alters streambank geometry in the region. Additionally bridge contractions caused local scouring on the stream bed. Bridge peers reduce velocity of water correspondingly stream power for sediment transport. Recently two arches of the historic bridge were filled with sediment at the downstream course of the study area. From 1995 to 2016, the width of the stream at the Historic Sakarya Bridge has reduced $\sim 30 \mathrm{~m}$, so the stream flows through the bridge using one arch.

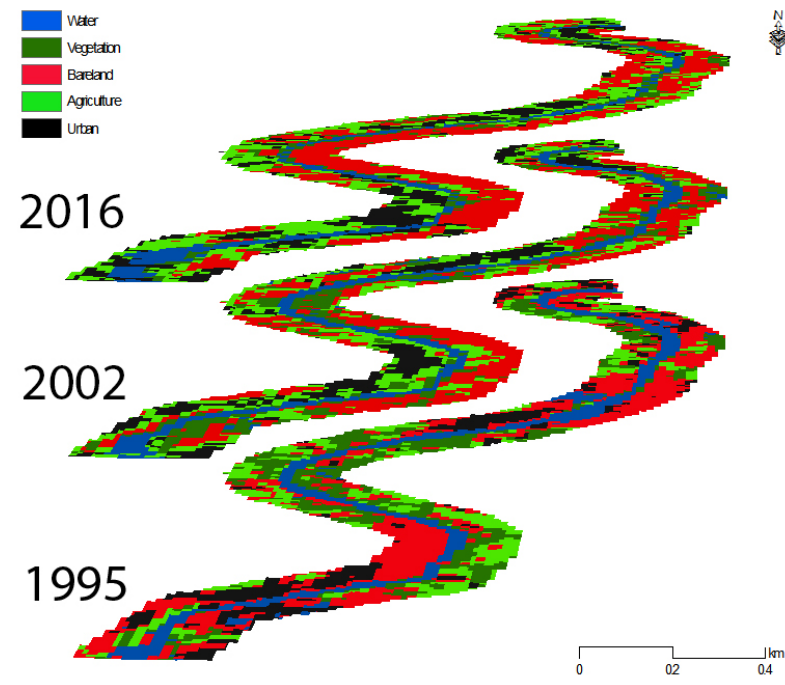

Fig. 2. Land use change along Sakarya River between 1995 and 2016

In the last three decades due to extensive changes in land use along the river, stream bank erosion rate has been increased. Population growth in the research area is significant in the past 3 decades, resulting expanding industrial as well as other anthropogenic activities around the stream channel. Change in land use type from agriculture to industrial usage has disturbed nature of channel dynamics. From satellite images, anthropogenic activities in the buffered zone has been increased as a result of construction infrastructures, settlements and industrial operations, so the displacement of streambanks varied from 0.29 to 0.18 in 1995 and 2016, respectively.

\section{CONCLUSIONS}

In conclusion, the results demonstrate that an integrated approach of RS and GIS to monitor anthropogenic impact by overlaying different land use maps can be a reasonable tool for streambank stability. Human induced hydrological changes in the channel such as dam construction and sand mining have a significant effect on changing streambank stability through years. Most noticeable human activities are dam construction and instream mining operations in this region. It should be noted here that the stream showing more steady stream characteristics especially after the HES construction. Also sand extraction in active channel has a significant impact on streambank mobility. Change in land use type from agriculture to industrial usage has been observed in the region. Such studies need to be supported and taken into consideration before river restorations because better understanding of how stream response to land use changes through years especially for a river flowing through densely populated areas is a significant task for a feasible river restoration practices.

\section{REFERENCES}

[1] G. M. Kondolf, "Hungry Water: Effects of Dams and Gravel Mining on River Channels Profile”, Environmental Management, vol. 21, no. 4, pp. 533-551, 1997.

[2] R. Rosso, M. C. Rulli, and D. Bocchiola, "Transient catchments hydrology after wildfires in a Mediterranean watershed: Runoff, sediment and woody debris”, Hydrol. Earth System Sci., vol. 11, no. 1, pp. 125- 140, 2007.

[3] D. Knighton, Fluvial Forms \& Processes: A New Perspective. Arnold, New York, 383 p., 1998.

[4] S. Wenger, A review of the scientific literature on riparian buffer width, extent and vegetation. Athens. GA: Office of Public Service and Outreach, Institute of Ecology, University of Georgia, 59 p., 1999.

[5] S. Ashraf, H. Afshari, and A.G. Ebadi, “Application of GIS for determination of groundwater quality suitable in crops influenced by irrigation water in the Damghan region of Iran”, Int. J. Phy. Sci., 6, no. 4, pp. 843-854, 2011.

[6] B. Gopal, "River conservation in the Indian sub-continent" in P.J. Boon, B.R. Davies and G.E. Petts, (Eds.), Global Perspectives on River Conservation. Science, Policy and Practice. Wiley, Chichester, 2000, pp. 233-261.

[7] M. Islam, Fakrul, Higano and Yoshiro, "Attainment of Economic Benefit through Optimal Sharing of International River Water: A Case Study of the Teesta River”, Indian Journal of Regional Science, vol. 34(2), pp. 1-10, 2002.

[8] N.J. Schofield, K.J. Collier, J. Quinn, F. Sheldon, F., and M.C. Thoms, "River conservation in Australia and New Zealand", in P.J. Boon, B.R. Davies and G.E. Petts, (Eds.), Global Perspectives on River Conservation. Science, Policy and Practice. Wiley, Chichester, 2000.

[9] M. Yamani, A. Goorabi, and J. Dowlati, "The Effect of Human Activities on River Bank Stability (Case Study)”, American Journal of Environmental Sciences, vol. 7, no. 3, pp. 244-247, 2011.

[10] J.R. Wallick, S.T. Lancaster, and J.P. Bolte "Determination of bank erodibility for natural and anthropogenic bank materials using a model of lateral migration and observed erosion along the Willamette River, Oregon USA”, River Research and Applications, vol. 22, no. 6, pp. 631-649, 2006. 